\title{
Gambaran Pengetahuan dan Sumber Informasi tentang Pemeriksaan Payudara Sendiri (SADARI) pada Siswi Sekolah Menengah Kesehatan (SMK) ‘Aisyiyah Palembang Tahun 2016
}

\author{
Risa Devita \\ Program Studi DIII Kebidanan, Sekolah Tinggi Ilmu Kesehatan 'Aisyiyah Palembang \\ Jl. Kol. H. Burlian KM. 7,5, Karya Baru, Alang Alang Lebar, Kota Palembang, Sumatera Selatan 30153 \\ Email: risa_devita@yahoo.com
}

\begin{abstract}
ABSTRAK
Kanker payudara sebagai jenis kanker yang paling banyak ditemui pada wanita. Pusat Data dan Informasi Kementerian Kesehatan Republik Indonesia menyatakan bahwa prevalensi kanker tertinggi di Indonesia pada tahun 2013 adalah kanker payudara sebesar 0,5\%. Berdasarkan Laporan Pusat Data\&Informasi Kemenkes, Provinsi Sumatera Selatan pravalensi dan estimasi kanker payudara tahun 2013 sebesar 0,2\% atau 772 orang. Tujuan penelitian ini untuk mengetahui gambaran pengetahuan dan sumber informasi dengan pemeriksan payudara sendiri (SADARI) pada siswi Sekolah Menengah Kesehatan (SMK) 'Aisyiyah Palembang tahun 2016. Metode penelitian secara survey analitik dengan pendekatan cross sectional. Sampel minimal penelitian ini adalah siswi kelas X dan XI sebanyak 98 responden dengan teknik Stratified random sampling. Hasil analisis univariat terhadap 98 responden, didapatkan 49,0\% yang melakukan pemeriksaan payudara sendiri, 34,7\% yang berpengetahuan baik, dan $10,2 \%$ yang memiliki sumber informasi banyak.
\end{abstract}

Kata Kunci: Pengetahuan, Sumber Informasi, Pemeriksaan Payudara Sendiri (SADARI)

\section{Overview of Knowledge and Sources of Information with Breast Self-Examination (BSE) in High School Health Students 'Aisyiyah Palembang Year 2016}

\begin{abstract}
Breast cancer is a type of cancer that is most common in women. Based on the result of Data and Information Ministry of Health Republic of Indonesia (2015), the highest prevalence in Indonesia in 2013 for breast cancer by $0.5 \%$. In South Sumatera have a high prevelence and the estimated amount of $0.2 \%$ or 772 people. The purpose of this research to get correlation of knowledge and information's with Breast Self-Examination (SADARI) on Health High School Students' of Aisyiyah Palembang 2016. This research using analytical survey method with cross sectional approach with samples partially students of class X and XI were 98 respondents and using stratified random sampling technique. The results of the univariate analysis of the 98 respondents, obtained $49.0 \%$ who did breast self-examination, $34.7 \%$ were knowledgeable good, and $10.2 \%$ who have a lot of informations.
\end{abstract}

Keywords: Knowledges, Informations, Breast Self-Examination (BSE)

\section{Pendahuluan}

Kanker payudara adalah tumor ganas pada jaringan payudara, kanker payudara terjadi karena adanya kerusakan gen yang mengatur pertumbuhan dan diferensiasi sehingga sel tumbuh dan berkembang biak tak terkendali. ${ }^{1}$

$$
\text { Menurut World Health Organization }
$$

(WHO) 2005-2015 pravelensi kanker payudara pada wanita sebanyak 8-9\% dimana kanker 
payudara sebagai jenis kanker yang paling banyak ditemui pada wanita. Setiap tahun lebih dari 250.000 kasus baru kanker payudara terdiagnosis di Eropa dan kurang lebih 175.000 di Amerika Serikat. ${ }^{2}$ Penyakit kanker serviks dan payudara merupakan penyakit kanker dengan prevalensi tertinggi di Indonesia pada tahun 2013, yaitu kanker serviks sebesar 0,8\% dan kanker payudara sebesar $0,5 \%$. Prevalensi kanker payudara tertinggi terdapat pada Provinsi D.I. Yogyakarta, yaitu sebesar 2,4\%. Untuk Provinsi Sumatra Selatan memiliki pravalensi dan estimasi jumlah penderita kanker serviks $0,4 \%$ (1.544 orang) dan kanker payudara yaitu sebesar $0,2 \%$ atau 772 orang. ${ }^{3}$ Penelitian dilakukan di Palembang dikarenakan keterbatasan peneliti dan merupakan penelitian dasar dimana hasil penelitian hanya berupa gambaran saja.

Pemeriksaan payudara sendiri (SADARI) merupakan cara sederhana menemukan kelainan payudara sendiri sedini mungkin, apabila terdapat benjolan pada payudara, terutama yang dicurigai ganas, sehingga dapat menurunkan angka kematian. ${ }^{4}$ Pemeriksaan payudara sendiri untuk mendeteksi kanker payudara harus disosialisasikan lebih gencar. SADARI adalah cara termudah dan termurah untuk mengetahui adanya benjolan yang kemungkinan besar berkembang menjadi kanker. Tindakan ini menjadi kebiasaan karena mudah, murah, cepat, dan efektif untuk semakin mengenal dan menyadari jika terdapat suatu hal yang tidak normal pada payudara. ${ }^{5}$

Pada penelitian ini peneliti mengambil responden remaja (remaja putri) dikarenakan pada berdasarkan penelitian sebelumnya yang dijadikan referensi pada penelitian ini bahwa masih ada remaja putri yang belum mengetahui dengan baik tentang SADARI padahal SADARI merupakan cara termudah dan termurah untuk mengetahui adanya benjolan yang kemungkinan besar berkembang menjadi kanker.

Penelitian yang dilakukan oleh Tanjung (2012), tentang Gambaran Pengetahuan dengan Perilaku Pemeriksaan Payudara Sendiri Pada Siswa di salah satu SMA di Medan mendapatkan hasil bahwa responden memiliki pengetahuan yang baik yaitu $84,45 \%$ yang di dukung dengan media informasi yang baik $(84,44 \%)$ serta responden telah melakukan tindakan SADARI dengan kategori baik $(75,56 \%){ }^{6}$ Penelitian lain yang dilakukan Fatmawati di salah satu SMA Palembang (2014) tentang Hubungan Pengetahuan dan Sumber Informasi dengan Pemeriksaan Payudara Sendiri didapatkan hasil bahwa 77 responden, didapatkan $46,8 \%$ yang melakukan pemeriksaan payudara sendiri, $67,5 \%$ yang berpengetahuan baik, dan 51,9\% yang memiliki sumber informasi banyak. ${ }^{7}$ Hasil Penelitian Erviana (2015), di salah satu SMA di Semarang tentang Hubungan Pengetahuan dan Sikap Siswa Putri tentang Kanker Payudara Terhadap Pemeriksaan Payudara Sendiri (SADARI) diketahui bahwa sebanyak 40 responden (50,6\%) memiliki pengetahuan yang kurang tentang kanker payudara, 45 responden $(57 \%)$ memiliki sikap negatif tentang SADARI, dan sebanyak 65 responden $(82,3 \%)$ yang tidak mampu melakukan SADAR. ${ }^{8}$ 
Berdasarkan data dan latar belakang diatas maka peneliti tertarik untuk melakukan penelitian tentang "Gambaran Pengetahuan dan Sumber Informasi dengan Pemeriksaan Payudara Sendiri (SADARI) pada Siswi Sekolah Menengah Kesehatan (SMK) 'Aisyiyah Palembang Tahun 2016".

\section{Metode Penelitian}

Jenis penelitian ini adalah observasional deskriptif dengan pendekatan cross sectional. Sampel minimal dalam penelitian ini adalah siswi kelas $\mathrm{X}$ dan $\mathrm{XI}$ SMK 'Aisyiyah Palembang sebanyak 98 responden. SMK Aisyiyah Palembang adalah sekolah menengah kesehatan dengan keahlian farmasi, peneliti berasumsi seharusnya karena mereka sekolah di sekolah kejuruan kesehatan sedikit banyak sudah mendapatkan informasi tentang SADARI tetapi berdasarkan studi pendahuluan yang dilakukan peneliti dengan mewawancarai beberapa siswi (10 siswi) secara random, hanya sebagian kecil yang mengetahui tentang SADARI sehingga peneliti memilih SMK Aisyiyah Palembang sebagai tempat penelitian. Sampel diambil dengan metode stratified random sampling.

Variabel yang akan diteliti pada penelitian ini adalah pemeriksaan payudara sendiri (SADARI), pengetahuan dan sumber informasi sebagai variabel bebas. Penelitian ini menggunakan kuesioner sebagai instrument penelitian yang telah dilakukan uji validitas dan reabilitas pada sampel dengan kriteria yang sama dengan sampel penelitian sesungguhnya.

Kuesioner tersebut berisi daftar pertanyaan yang mewakili masing-masing variabel. Untuk variabel Pemeriksaan SADARI dengan 10 pertanyaan, variabel pengetahuan 15 pertanyaan, variabel media informasi 10 pertanyaan.

Metode pengolahan data yaitu editing, koding, skoring, tabulating dan entry data dan analisis dengan menggunakan SPSS 17. Analisis dilakukan secara analisis univariat untuk melihat gambaran masing-masing variabel.

\section{Hasil}

Dari tabel 1 dapat diketahui bahwa responden yang tidak melakukan SADARI lebih banyak (51\%) dibanding responden yang tidak melakukan SADARI (49\%). Sebagian besar responden memiliki pengetahuan yang kurang tentang SADARI (65,3\%) dan sebagian besar responden mendapat informasi yangs sedikit tentang SADARI $(89,8 \%)$.

Tabel 1. Distribusi Responden Menurut Pemeriksan Payudara Sendiri, pengetahuan dan sumber informasi

\begin{tabular}{lcc}
\hline Variabel & n & $\%$ \\
\hline Pemeriksaan Payudara & & \\
Sendiri (SADARI) & & \\
Tidak Melakukan & 40 & 51 \\
Melakukan & 48 & 49 \\
Pengetahuan & & \\
Kurang Baik & 64 & 65,3 \\
Baik & 34 & 34,7 \\
Sumber Informasi & & \\
Sedikit & 88 & 89,8 \\
Banyak & 10 & 10,2 \\
\hline
\end{tabular}




\section{Pembahasan}

Berdasarkan Tabel 1 diketahui bahwa sebagian besar responden tidak melakukan pemeriksaan payudara sendiri (SADARI) yaitu sebesar 51\%. Sebagian besar responden dengan pengetahuan kurang baik yaitu sebesar $65,3 \%$. Sebagian besar responden dengan memiliki sedikit sumber informasi yaitu 89,8\%.

Penelitian ini sejalan dengan penelitian Tanjung (2012) tentang Gambaran Pengetahuan dengan Perilaku Pemeriksaan Payudara Sendiri Pada Siswa di salah satu SMA di Medan mendapatkan hasil bahwa responden memiliki pengetahuan yang baik yaitu $84,45 \%$ yang didukung dengan media informasi yang baik $(84,44 \%)$ serta responden telah melakukan tindakan SADARI dengan kategori baik $(75,56 \%){ }^{6}$

Penelitian lain yang dilakukan Fatmawati di salah satu SMA Palembang (2014) tentang Hubungan Pengetahuan dan Sumber Informasi dengan Pemeriksaan Payudara Sendiri didapatkan hasil bahwa 77 responden, didapatkan $46,8 \%$ yang melakukan pemeriksaan payudara sendiri, $67,5 \%$ yang berpengetahuan baik, dan 51,9\% yang memiliki sumber informasi banyak. ${ }^{7}$

Begitu juga dengan hasil penelitian Erviana (2015), di salah satu SMA di Semarang tentang Hubungan Pengetahuan dan Sikap Siswa Putri tentang Kanker Payudara Terhadap Pemeriksaan Payudara Sendiri (SADARI) diketahui bahwa sebanyak 40 responden $(50,6 \%)$ memiliki pengetahuan yang kurang tentang kanker payudara, 45 responden (57\%) memiliki sikap negatif tentang SADARI, dan sebanyak 65 responden $(82,3 \%)$ yang tidak mampu melakukan SADARI. ${ }^{8}$

Berdasarkan hasil penelitian, peneliti berasumsi bahwa perilaku pemeriksaan payudara sendiri oleh siswi masih rendah karena belum banyaknya yang mengetahui tentang tujuan, manfaat ataupun prosedur pemeriksaan payudara sendiri dan sedikitnya informasi yang responden dapatkan tentang pemeriksaan payudara sendiri (SADARI).

Kecenderungan seseorang untuk melakukan tindakan pencegahan penyakit sangat ditentukan oleh pengetahuan. Seseorang yang berpengetahuan baik tentang SADARI dapat meningkatkan keinginan atau motivasi untuk melakukan pemeriksaan payudara sendiri sehingga perilaku yang dilakukan memiliki tujuan dan alasan yang jelas. Melakukan pemeriksaan payudara sendiri dengan pengetahuan yang dimiliki akan memberikan kesadaran untuk melakukan pemeriksaan payudara sendiri secara lebih mantap dan mendalam sehingga akan lebih menyadari untuk mendeteksi adanya kanker payudara.

Semakin banyak sumber informasi yang didapatkan seseorang dapat memperbanyak pengetahuan sehingga meningkatkan kesadaran seseorang untuk melakukan suatu tindakan yang diyakini memiliki tujuan dan alasan yang kuat untuk mencapai suatu keinginan. Sehingga jumlah sumber informasi tentang SADARI yang didapatkan siswi berpengaruh terhadap perilaku pemeriksaan payudara sendiri. 


\section{Kesimpulan}

Dari hasil penelitian ini di simpulkan bahwa sebagian besar responden tidak melakukan pemeriksaan payudara sendiri (SADARI) yaitu sebesar $51 \%$, sebagian besar responden dengan pengetahuan kurang baik yaitu sebesar $65,3 \%$ dan sebagian besar responden memiliki sedikit sumber informasi yaitu $89,8 \%$.

\section{Daftar Pustaka}

1. Suryani, R \& Tiurna,R. 2014. PrinsipPrinsip Dasar Praktik Kebidanan. Jakarta: Dunia Cerdas.

2. Masriadi. 2016. Epidemiologi Penyakit Tidak Menular. Jakarta: CV. Trans Info Media.

3. Kemenkes, 2015. Pusat Data dan Informasi Kementrian Kesehatan RI, at http://www.depkes.go.id/resources/downlo ad/pusdatin/infodatin/infodatin-kanker.pdf.

4. Nugroho, Taufan. 2011. ASI dan Tumor Payudara. Yogyakarta: Mulia Medika.

5. Savitri, dkk. 2015. Kupas Tuntas Kanker Payudara, Leher Rahim, dan Rahim. Yogyakarta: Pustaka Baru Press.

6. Tanjung, Masdiana. 2015. Gambaran Perilaku Siswi dalam Pemeriksaan Payudara Sendiri (SADARI) di SMA Plus Safiyyatul Amaliyyah Tahun 2012. Jurnal Kebijakan, Promosi Kesehatan dan Biostatistika, Vol 2 Tahun 2016, Hal 30-40.

7. Fatmawati. 2014. Hubungan Pengetahuan dan Sumber Informasi dengan Pemeriksaan Payudara Sendiri di SMA Negeri 9 Palembang. Jurnal Kebijakan,
Promosi Kesehatan dan Biostatistika, Volume 2 Tahun 2015, Hal 31-42.

8. Erviana. 2015. Hubungan Antara Pengetahuan dan Sikap Siswa Putri Tentang Kanker Payudara Terhadap Pemeriksaan Payudara Sendiri di SMA N 14 Semarang. Jurnal STIKES Telogorejo Semarang, Volume 1 Tahun 2016, Hal: 115. 